\title{
Weather Based Approach for Effective Management of Bacterial Blight of Pomegranate caused by Xanthomonas axonopodis pv. punicae
}

\author{
B. Hanumanthe Gowda*, P. R. Ramesh and J. M. Prashanth
}

Krishi Vigyan Kendra, Hirehalli, Tumkur-572168, India

*Corresponding author

\begin{abstract}
A B S T R A C T
Bacterial blight of Pomegranate caused by Xanthomonas axonopodis pv. punicae has become a major constraint in important pomegranate producing states of Maharashtra, Karnataka and Andhra Pradesh of India. A field demonstration trials on management of

Bacterial Blight was implemented as cluster approach in an five orchards having five years old 'Bhagwa' cultivar during the year 2014-15 and 2015-16 at Nidagallu hobli of Pavagada Taluk. Adoption of an integrated disease management schedule jointly developed by NRCP-Sholapur and IIHR, Bengaluru, which included practices like orchard sanitation, avoidance of rainy season crop (Mrig bahar) and regulating the Hasta bahar crop, judicious sprays of antibiotic like Streptocycline $(500 \mathrm{ppm})$ in combination with fungicides like carbendazim $(0.15 \%)$ or mancozeb $(0.2 \%)$ or copper oxychloride $(0.25 \%)$ or Bordeaux mixture $(0.1 \%)$ at 15 days intervals based on the prevailing weather conditions of the cluster. It was evident that Bacterial blight per cent to the extent of 15.8 and $13.8 \%$ was recorded in September first and second fortnight pruned crop. Moderate disease intensity was recorded in October pruned crop and more disease severity of $60.7 \%$ was recorded in November second fortnight pruned crop owing to the prevalence of congenial weather factors such as temperature, relative humidity and rainfall. Results of the study on rest period indicated that minimum disease index of $6.59 \%$ was recorded in the crop given six months rest and high disease severity of $80.36 \%$ was recorded in crop given one month rest.
\end{abstract}

\section{Keywords}

Bacterial Blight, Pomegranate, Weather parameters

Article Info

Accepted:

12 August 2020

Available Online:

10 September 2020

\section{Introduction}

Pomegranate (Punica granatum), so called "fruit of paradise" is one of the major fruit crops of tropical and subtropical region. The fruit is grown for its attractive, juicy, sweetacidic and fully luscious grains. The fruits are mainly used for dessert purposes. It is one of the most adaptable subtropical minor fruit crops and its cultivation is increasing very rapidly. In India, it is regarded as a "vital cash crop". In India it is grown in an area of 1.25 lakh hectares with 60.64 lakh tones of production. In Karnataka, it is grown in an area of 14,000 hectares with production of 1.5 lakh tonnes and productivity of 10 tonnes per hectare. Pomegranate occupies sixth place in the fruit export market of India, where it accounts for 50 per cent of world pomegranate production and earns foreign 
exchange to the tune of Rs. 270 crores. The most popular varieties suitable for processing and table use are Ganesh, Mridula, Arakta, Bhagwa, Kesar, G-137 and Khandar.

Successful cultivation of Pomegranate in recent years has met with different traumas such as pest and diseases. Among diseases bacterial blight in pomegranate caused by Xanthomonas axonopodis pv. punicae (Vauterin et al., 1995) is a major threat.

The survey conducted by NRC Pomegranate from 2005 to 2009 revealed that prevalence of blight incidence was mild to severe. Prevalence of Bacterial blight in Karnataka was $58.33 \%$, of which $27.77 \%$ orchards had moderate blight and $33.05 \%$ orchards had mild infections (Anon. 2008, 2009) Bacterial blight resulted in yield losses to the extent of during 2007-08 as the production drastically reduced to 1.18 million tonnes in 2003-04 to mere ten thousand tonnes in the year 2007-08 just span of four years in Karnataka (Benagi and Ravikumar, 2009)

The disease initiates through wounds and its spread is influenced by increased day temperature, low humidity and rain. The bacteria overwinter in infected plant leaves, stems and fruits. The first water- soaked lesions develop within 2-3 days and appear as dark red spots. Disease buildup is rapid from July to September. Severity increases during June and July and reaches a maximum in September and October and then declines. Bacterial cells are capable of surviving in soil for more than 120 days and also survive in fallen leaves during the off-season. High temperatures and low humidity or both favour disease development.

Any successful plant protection that depends on early detection of the disease followed by timely adoption of control measures. In view of enormous losses which may extend up to
$60-80 \%$ in unmanaged orchards under epidemic conditions, the present study was undertaken with the objective to ascertain the disease management schedule in correlation with weather parameters.

\section{Materials and Methods}

Field demonstration trials on management of bacterial blight was implemented on cluster approach in five orchards of one acre each having 3-5 years old 'Bhagwa' cultivar of Hasta bahar cropping season during the year 2014-15 and 2015-16 at Madde village, Nidagallu hobli of Pavagada taluk situated in $14^{\circ} 8^{\prime} 43^{\prime \prime N}$ North and $77^{\circ} 5^{\prime} 37^{\prime \prime}$ East.

Farm advisory service and recommendation was provided to each farmer at fortnight intervals by studying the existing weather conditions and weather forecasting situations. The technology includes adoption of an integrated disease management schedule jointly developed by NRCP-Sholapur and IIHR, Bangalore, which included practices like orchard sanitation, avoidance of rainy season crop (Mrig bahar) and regulating the Hasta bahar crop, judicious sprays of antibiotic like Streptocycline (500 ppm) in combination with fungicides like carbendazim $(0.15 \%)$ or mancozeb $(0.2 \%)$ or copper oxychloride $(0.3 \%)$ or Bordeaux mixture $(0.1 \%)$ at 15 days intervals based on the prevailing weather conditions of the cluster recorded in the local meteorological unit situate at Hobli headquarters Nidagallu.

The observation on per cent disease incidence was recorded at fortnightly intervals through the cropping season. In addition to disease, marketable yield was also recorded. Benefit cost ratio was also worked out. The farmer's field situated in neighbouring village situated from $2.5 \mathrm{kms}$ from demonstration plot was served as control plot. 
Per cent incidence (Wheeder, 1969) on leaves, stem and fruit was calculated by applying the formula given below.

Leaf incidence $(\%)=\frac{\text { Number of Infected leaves }}{\text { Total leaves observed in a set }} \times 100$
Twig incidence $(\%)=\frac{\text { No. of stems or twigs infected }}{\text { Total stems observed in a set. }} \times 100$

Fruit incidence $(\%)=\frac{\text { Number of infected fruits }}{\text { Total fruits observed in a set }} \times 100$

Studies on cropping season on Disease incidence

One farmer field was selected to study the effect of all three cropping seasons on disease incidence. The field size was of half an acre for each of bahar treatment. The packages of practices were followed for all the three treatments. The observations on disease incidence and yield were recorded.

\section{Results and Discussion}

The field demonstration trials on management of bacterial blight were implemented in different farmer's field of Pavagada taluk. The results revealed that minimum leaf blight incidence was noticed in all the farmers field with the mean incidence of 26.15 per cent compare to check plot $(64.28 \%)$. This is due to prevalence of congenial weather factors such as temperature, relative humidity and rainfall. The average temperature was recorded during the cropping season particularly Summer/ Kharif was 30-35C with the average humidity of 30 to $50 \%$.

The results from table 1 and 2 also indicated that the mean per cent stem blight incidence of 52.82 per cent was recorded in control plot as against treatment field which recorded 24.85 per cent, which significantly superior over the control plot. The disease incidence among farmers field was on par in each plot. Similar trend of results was also obtained in per cent fruit blight, which recorded the least incidence of 11.18 per cent compared to 28.61 per cent in control plot. This may be due to presence of suitable environmental parameters for pathogen like high rainfall and temperature around $30-35^{\circ} \mathrm{C}$ which helps to spread of pathogen propagule.

The yield obtained in demo field was significantly superior over the control field which recorded the least yield of $5.40 \mathrm{t} / \mathrm{ha}$ compared to demo field which recorded 7.85 t/ha. The highest per cent increase in yield over control was recorded in demo field III (DF-III) of 60.89 per cent and least was in DF-V (33.87\%).

The benefit cost ratio was recorded ranges from 4.98 to 6.28 compare to check plot (1:3.13).

Studies on effect of cropping seasons on disease incidence and yield (Table 2) indicated that the highest disease was recorded in Hasta bahar season followed by Mrig bahar. The results confirmed with studies of Benagi et al., (2009) who reported that the severity of disease was more during Mrig bahar. He also reported that it was in severe form in the all pomegranate growing areas, which ranged from $0.67-94.80 \%$ of severity on a tree.

The maximum leaf blight per cent was recorded in Mrig bahar (26.41\%) and least was in Ambe bahar (19.12). But the trend in case of stem and fruit blight was different where highest disease per cent was recorded in Hasta bahar followed by Mrig bhar.

The highest yield was recorded in Ambe bahar (8.92 t/ha) followed by Mrig bahar (7.31t/ha) and Hasta bahar (6.58 t/ha). 
Table.1 Average incidence of bacterial blight of pomegranate in demonstration field and check plot during the year 2011-12 and 2012-13

\begin{tabular}{|c|c|c|c|c|c|c|}
\hline $\begin{array}{l}\text { Farmer's } \\
\text { field }\end{array}$ & $\begin{array}{c}\text { \% Leaf } \\
\text { blig }\end{array}$ & $\begin{array}{l}\% \text { Stem } \\
\text { blight }\end{array}$ & $\begin{array}{l}\text { \% Fruit } \\
\text { blight }\end{array}$ & $\begin{array}{l}\text { Yield } \\
\text { t/ha }\end{array}$ & $\begin{array}{l}\text { \% increase } \\
\text { over control }\end{array}$ & B:C ratio \\
\hline DF-I & $\begin{array}{c}26.82 \\
(31.12)^{*}\end{array}$ & $\begin{array}{c}26.10 \\
(30.52)\end{array}$ & $\begin{array}{c}9.82 \\
(18.23)\end{array}$ & 7.95 & 47.19 & $1: 5.12$ \\
\hline DF-II & $\begin{array}{c}27.62 \\
(31.69)\end{array}$ & $\begin{array}{c}23.01 \\
(28.48)\end{array}$ & $\begin{array}{c}11.33 \\
(19.65)\end{array}$ & 8.00 & 48.00 & $1: 4.98$ \\
\hline DF-III & $\begin{array}{c}24.94 \\
(29.83)\end{array}$ & $\begin{array}{c}25.16 \\
(30.05)\end{array}$ & $\begin{array}{c}12.82 \\
(20.89)\end{array}$ & 8.69 & 60.89 & $1: 6.28$ \\
\hline DF-IV & $\begin{array}{c}24.38 \\
(29.54)\end{array}$ & $\begin{array}{c}27.65 \\
(31.69)\end{array}$ & $\begin{array}{c}13.63 \\
(21.64)\end{array}$ & 7.23 & 33.87 & 1: 5.07 \\
\hline DF-V & $\begin{array}{c}26.99 \\
(31.18)\end{array}$ & $\begin{array}{c}22.34 \\
(28.19)\end{array}$ & $\begin{array}{c}8.30 \\
(16.70)\end{array}$ & 7.38 & 36.59 & $1: 5.82$ \\
\hline Mean of Demo. field & 26.15 & 24.85 & 11.18 & 7.85 & - & - \\
\hline Check & $\begin{array}{c}64.28 \\
(53.32)\end{array}$ & $\begin{array}{c}52.82 \\
(46.75)\end{array}$ & $\begin{array}{c}28.61 \\
(32.21)\end{array}$ & 5.40 & - & $1: 3.13$ \\
\hline SEM \pm & 1.61 & 3.20 & 1.18 & 0.38 & - & - \\
\hline CD at $5 \%$ & 5.13 & 10.20 & 3.76 & 1.23 & - & - \\
\hline
\end{tabular}

DF: Demo Field. *=Figures in the parenthesis are angular transformed values

Table.2 Effect of cropping seasons on disease incidence and yield

\begin{tabular}{|l|c|c|c|c|c|}
\hline Cropping Season & $\begin{array}{c}\text { \% Leaf } \\
\text { blight }\end{array}$ & $\begin{array}{c}\text { \% Stem } \\
\text { blight }\end{array}$ & $\begin{array}{c}\text { \% Fruit } \\
\text { blight }\end{array}$ & $\begin{array}{c}\text { Yield } \\
\text { t/ha }\end{array}$ & B:C ratio \\
\hline Mrig bahar & 26.41 & 28.89 & 16.19 & 7.31 & $1: 5.11$ \\
\hline Hasta bahar & 15.81 & 35.81 & 19.01 & 6.58 & $1: 4.60$ \\
\hline Ambe bahar & 19.12 & 24.77 & 9.13 & 8.92 & $1: 6.23$ \\
\hline Mean & $\mathbf{2 0 . 4 5}$ & $\mathbf{2 9 . 8 2}$ & $\mathbf{1 4 . 7 8}$ & $\mathbf{7 . 6 0}$ & - \\
\hline
\end{tabular}

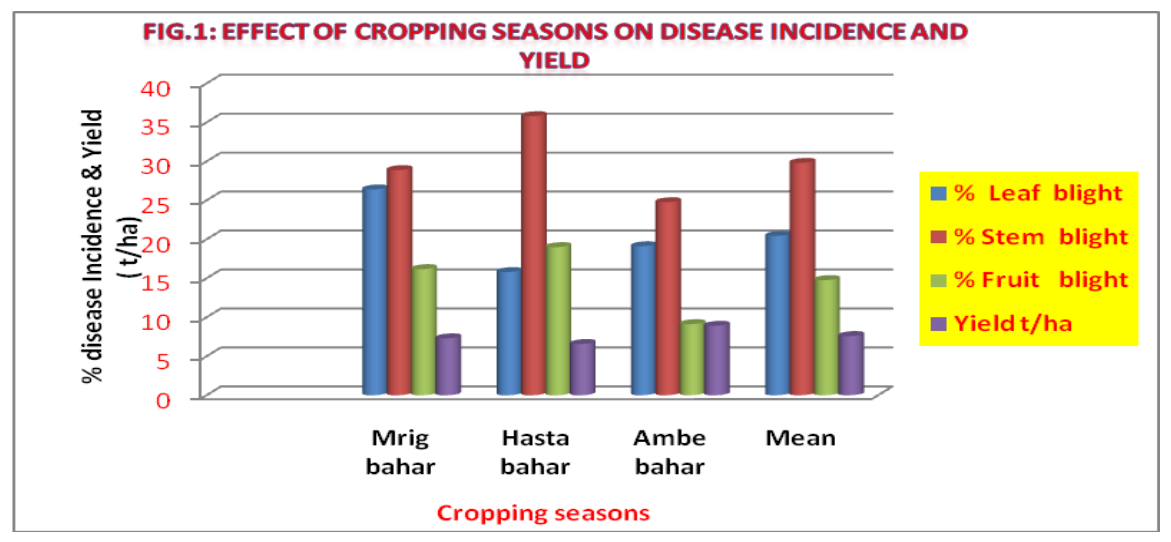

The present findings are also in conformity with the work of Manjula and Khan (2002), who reported the devastating nature of bacterial blight of pomegranate on all the varieties, irrespective of age of the plant during late summer and kharif season of 
2001-02. Among the seasons, Mrig bahar was found more vulnerable than Ambe bahar and Hast bahar because of environmental factors like rainfall and temperature which are less in Ambe bahar (January-February) and Hasta bahar (September-October) season.

\section{Acknowledgement}

Authors are greatly acknowledged to the Director, IIHR and ATARI, Bengaluru for providing the facilities and financial assistance for this study.

\section{References}

Anonymous, 2007, Studies on important pomegranate pests and diseases. In: Annual report 2006-07 of National Research centre on Pomegranate. Solapur, India, Pp: 13-24.

Anonymous, 2008, Studies on important pomegranate pests and diseases. In:
Annual report 2007-08 of National Research centre on Pomegranate. Solapur, India, Pp: 24-46.

Benagi, V. I., Ravi Kumar, M. R., Gowdar S. B. and Basavarj B. B., 2009, Survey on diseases of pomegranate in northern Karnataka. Paper Presented In: 2nd Int. Symp. Pomegranate and Minor including Mediterranean Fruits, Univ. Agric. Sci., Dharwad, June 2327, pp. 135.

Manjula, C. P. and Khan, A. N. A., 2002, Incidence of bacterial blight of pomegranate (Punica granatum L.) in Karnataka. Paper presented at the Annu. Meet. Symp. Plant Disease Scenario in Southern India, held at Bangalore, December, 19-21, 2002.

Vauterin, L., Haste, B., Kersters, K. and Swings, J., 1995, Reclassification of Xanthomonas. Int. J. Syst. Bacterial., 45:475-489.

\section{How to cite this article:}

Hanumanthe Gowda, B., P. R. Ramesh and Prashanth, J. M. 2020. Weather Based Approach for Effective Management of Bacterial Blight of Pomegranate caused by Xanthomonas axonopodis pv. punicae. Int.J.Curr.Microbiol.App.Sci. 9(09): 1424-1428. doi: https://doi.org/10.20546/ijcmas.2020.909.180 